\title{
Impact of date palm pollen (Phoenix dactylifera) treatment on paracetamol- induced hepatorenal toxicity in rats
}

\author{
Abdulrahman Khazim Al-Asmari ${ }^{1 *}$, Mansour S. Al-Said ${ }^{2}$, Rajamohamed Abbasmanthiri ${ }^{1}$, Ahmed Al-Buraidi ${ }^{3}$, \\ Khalid Elfaki Ibrahim ${ }^{4}$ and Syed Rafatullah ${ }^{1}$
}

\begin{abstract}
Background: Consumption of plant-derived nutraceuticals and crude drugs in Arab traditional medicine is widely believed to confer beneficial effects in liver and kidney diseases. Fruits from the date palm Phoenix dactylifera L. are a rich source of nutrients and bioactive phytochemicals which possess a myriad of pharmacological effects. Herein, we examined the impact of Date Palm Pollen (DPP) aqueous suspension treatment on paracetamol (APAP) [Acetaminophen (APAP)] triggered hepatorenal damage in rats and further explored the underlying putative mechanism.
\end{abstract}

Methods: Thirty Wistar rats were assigned to five groups ( $n=6 /$ group). Group I was control group; animals in group II were administered APAP $1000 \mathrm{mg} / \mathrm{kg}$ body weight (b.w.) intraperitonealy (i.p.); Group III and IV administered APAP plus date palm pollen with doses of 50, $100 \mathrm{mg} / \mathrm{kg}$ b.w and group $V$ were administered APAP plus Silymarin (SIL) $10 \mathrm{mg} / \mathrm{kg}$ b.w. (i.p) respectively. Various biochemical parameters and histological assessment were evaluated in serum and tissue homogenate.

Results: Pretreatment with DPP aqueous suspensions (50 and $100 \mathrm{mg} / \mathrm{kg}$ b.w.) significantly $(p<0.05)$ thwarted APAP triggered alterations in serum biomarkers of liver damage [aspartate transaminase (AST), alanine aminotransferase (ALT), y-glutamyl transferase (GGT) and alkaline phosphatase (ALP)], serum albumin as well as bilirubin. DPP treatment further mitigated APAP triggered dyslipidemia associated with hepatic damage by influencing APAP elicited changes in serum levels of cholesterol, triglycerides, HDL, LDL and VLDL. DPP treatment significantly $(p<0.05)$ ameliorated extrahepatic manifestations of APAP toxicity by influencing alterations in parameters of renal function (creatinine, urea and uric acid) as well serum electrolytes (Sodium, Potassium and Calcium). DPP treatment further influenced APAP-induced histological lesions by curtailing necrosis and inflammatory changes in the hepatic and renal architecture, respectively. Furthermore, DPP treatment modulated APAP-induced redox imbalance in the hepatic and renal tissue by blunting the increase of malondialdehyde (MDA) as well as decrease of nonprotein sulfhydryls (NP-SH) significantly $(p<0.05)$ when compared with control. The protective effect of DPP was further confirmed histologically.

Conclusions: The present observations point to an hepatorenal protective effects of acute DPP treatment in APAP-intoxicated rats which is underpinned by its robust antioxidant properties.

Keywords: Date palm pollen, APAP, nephrotoxic, Hepatotoxic, Silymarin

\footnotetext{
* Correspondence: abdulrahman.alasmari@gmail.com

${ }^{1}$ Scientific Research Center, Medical Service Department (MSD), Ministry of

Defense, P.O. Box: 22454, Riyadh 11495, Kingdom of Saudi Arabia

Full list of author information is available at the end of the article
} 


\section{Introduction}

Consumption of plant-derived nutraceuticals and crude drugs in herbal folk medicine is widely believed to confer beneficial effects in liver and kidney diseases. Fruits from the date palm Phoenix dactylifera L. (Arecaceae) which are cultivated in arid regions are widely consumed in a variety of culinary preparations worldwide [1]. Dates are a rich source of dietary fibres, vitamins and minerals. A number of in vitro and in vivo studies have been performed to substantiate their use in folk medicine [1, 2]. Date extracts were shown to possess a myriad of pharmacological properties such as antioxidant [3], anti-inflammatory [4], antiatherogenic [5], hepatoprotective [6], anticancer [6], nephroprotective [7], antimicrobial [8], antiallergic [9], immunostimulatory [10], neuroprotective [11], antifungal [12], antimutagenic [13] and gastrointestinal transition stimulatory activity [14]. Date supplementation was shown to be beneficial in Alzheimer's disease transgenic mice model [15]. The putative pharmacological effects of dates are attributed to their bioactive constituents with robust antioxidant effects such as tannins [16] and polyphenols which comprise of phenolic acids, hydroxybenzoic and hydroxycinnamic acids, flavonoid glycosides, and proanthocyanidins [17-21]. Other parts of the date palm such as pits were shown to possess robust antibacterial, antifungal and antiviral properties $[22,23]$. Date pit extract was further shown to thwart DNA damage and mediate antigenotoxic effects [24].

Previous studies have reported that date palm pollen (DPP) possesses allergenic and antigenic components [25]. Mounting evidence, however, suggests that DPP has a variety of medicinally beneficial effects. Clinical studies have shown that DPP attenuates oral mucositis in patients [26] and shows anti-inflammatory as well as antiproliferative activities in rats [27]. Strikingly, recent studies have reported that DPP extracts mitigate testicular dysfunction triggered by cadmium toxicity and thryroid dysfunction [28] in mice. Along these lines, DPP was shown to influence fertility parameters in adult male rats [29]. Whether DPP administration influences hepatic and/or renal functions, however, remain elusive.

Paracetamol [also known as acetaminophen (APAP)]induced toxicity in animals is one of the widely used experimental model to investigate the hepatorenal protective activity of plant extract. In the present study, we explored whether and how DPP treatment influences hepatorenal function in rats. To this end, parameters of hepatic and renal function were examined following DPP administration in APAP-intoxicated rats.

\section{Materials and methods}

\section{Preparation of dosage form}

The DPP grain obtained from a date palm farm of Qassim Area, Saudi Arabia. Any visible contaminants and pieces of spathe were removed; the grain washed with tap water and sieved and dried. Shade dried pollen grain was made into fine powder using mortar and pestle. A $50 \mathrm{~g}$ of powder dissolved in $250 \mathrm{ml}$ of warm distilled water $\left(30^{\circ} \mathrm{C}\right)$ with constant shaking (magnetic shaker model). The solution was filtered. The water was evaporated and the yield was dissolved in isotonic solution to obtain required doses. The stock DPP solution was stored in a refrigerator protected from light at $4{ }^{\circ} \mathrm{C}$ until used.

\section{Chemicals and reagent}

All chemicals were obtained from Sigma (Sigma-Aldrich, St. Louis, MO, USA). Crescent and/or Roche Diagnostics kits (AST, ALT, ALP, Total Proteins, albumin, sodium, potassium, Cholesterol, Triglycerides, HDL, LDL, etc.) were used to determine the biochemical parameters estimation on Reflotron Plus Analyzer (Roche Diagnostics GmbH, Mannheim, Germany) and on a Shimadzu UV mini 1240 spectrophotometer (Shimadzu Europe, Milano, Italy) for the other measurement.

\section{Animals and monitoring}

Healthy male adult wistar albino rats (150-170 g) were obtained from the experimental animal care center, college of pharmacy, King Saud University (KSU), Riyadh, Saudi Arabia. After a 1-week adaptation period, rats were randomly divided into 5 groups (6 rats/cage) and kept at $22{ }^{\circ} \mathrm{C} \pm 2{ }^{\circ} \mathrm{C}, 55 \%$ humidity, and $12 / 12 \mathrm{~h}$-dark cycle. The animals were provided with Purina chow rat diet (UAR-Panlab, Barcelona, Spain) and drinking water ad libitum. All treatment protocols for this study were approved by the Ethics Committee of the Experimental Animal Care Society, KSU, Riyadh.

\section{Pre-treatment and APAP-induced hepatorenal toxicity}

Five groups $(\mathrm{I}-\mathrm{V})$ of animals were used. Group I served as normal control. Group II received only APAP $1000 \mathrm{mg} / \mathrm{kg}$ body weight (b.w) intraperitonealy (i.p) as intoxicated control. Groups III and IV were assigned as test groups. Group III and IV was pretreated with DPP at doses of 50 and $100 \mathrm{mg} / \mathrm{kg}$ b.w. orally consecutive for 14 days, whereas group $\mathrm{V}$ was pre-treated with silymarin at a dose of $10 \mathrm{mg} / \mathrm{kg}$ b.w. orally, for 14 days. Group I and II animals received a similar volume of vehicle (distilled water) once daily orally. At the 14th day, groups II-V received APAP in tween 80 at a dose of $1000 \mathrm{mg} / \mathrm{kg}$ b.w. intraperitonealy (i.p). After $24 \mathrm{~h}$, following APAP challenge, rats were euthanized by ether and then sacrificed and blood was collected by cardiocentesis and serum was obtained by centrifugation at $1000 \times g$ for $20 \mathrm{~min}$ 
at $4{ }^{\circ} \mathrm{C}$ and stored at $-70^{\circ} \mathrm{C}$ freezer. The liver and kidney were removed for biochemical and histological assessment.

\section{Analyses of serum hepatic enzymes and lipids}

Serum alanine aminotransferase (ALT) and AST, $\gamma$ glutamyl transferase (GGT), alkaline phosphatase (ALP) were determined calorimetrically by methods of Reitman and Frankel [30], Fiala, et al., [31] and King and Armstrong [32] respectively, whereas bilirubin was determined by the method of Stiehl [33]. Serum total cholesterol (TC), high-density lipoprotein cholesterol (HDL-C), and triglycerides (TG) were measured by the methods of Demacher and Hijamaus [34], Burstein and Scholnick [35] and Foster and Dunn [36] respectively, using Roche kits (Roche Diagnostics GmbH). Low-density lipoprotein cholesterol (LDL-C) and the very low-density lipoprotein-cholesterol (VLDL-C) levels were calculated from the formula: LDL-C $=$ TC-HDL-C-VLDLC; VLDL-C = TG/5.27.

\section{Analyses of serum creatinine, urea, uric acid and sodium,} potassium and calcium

Serum creatinine was measured by Jaffe reaction method using CS604 kit (Crescent Diagnostics, Jeddah, Saudi Arabia). Calcium was determined by o-cresolphthalein method described by Gitelman using CE500 kit (Crescent Diagnostics). Urea and uric acid were determined by urease and uricase methods described by Munan, et al. [37] and Fossati, et al., [38] respectively, using Roche kits (Roche Diagnostics $\mathrm{GmbH}$ ).

\section{Determination of lipid peroxidation}

A modified method of Utley, et al. [39] was used. The liver (or kidney) was homogenized in $0.15 \mathrm{M} \mathrm{KCl}$ at $4{ }^{\circ} \mathrm{C}$; and the homogenate $(10 \% \mathrm{w} / \mathrm{v}, 1 \mathrm{~mL})$ was transferred into a centrifuge tube and incubated at $37^{\circ} \mathrm{C}$ for $3 \mathrm{~h}$. Aqueous trichloroacetic acid (TCA, 10\%, $1 \mathrm{~mL}$ ) was then added and the mixture was centrifuged at $800 \times g$ for 10 min. The supernatant $(1 \mathrm{~mL})$ was removed and mixed with aqueous thiobarbituric acid (TBA, $1 \mathrm{~mL}, 0.67 \%$ ) and placed in a boiling water bath for $10 \mathrm{~min}$. The mixture was cooled, diluted with $1 \mathrm{~mL}$ distilled water, and
Absorbance was read at $535 \mathrm{~nm}$. The lipid peroxidation was expressed as malondialdehyde (MDA) in $\mathrm{nmol} / \mathrm{g}$ wet tissue using a standard curve of MDA dilutions according to the following equation: Absorbance of sample $\times 72.06 \times$ dilution factor/weight of sample in $g \times$ slope of standard curve.

\section{Estimation of nonprotein sulfhydryl groups}

Hepatic (or renal) nonprotein sulfhydryl (NP-SH) groups were measured according to the method of Sedlak and Lindsay [40] after homogenization in ice- old ethylenediaminetetraacetic acid (EDTA, 0.02 M). The homogenate $(5 \mathrm{~mL})$ was mixed with distilled water $(4 \mathrm{~mL})$ and TCA $(50 \%, 1 \mathrm{~mL})$, shaken for $10 \mathrm{~min}$ and then centrifuged. A supernatant $(2 \mathrm{~mL})$ was mixed with Tris buffer $(4 \mathrm{~mL}, 0.4 \mathrm{~mol} / \mathrm{L}, \mathrm{pH} 8.9)$ and 5,5 '-dithiobis-(2-nitrobenzoic acid) (DTNB, $0.1 \mathrm{~mL}$ ) was then added and shaken. Absorbance was measured within $5 \mathrm{~min}$ at $412 \mathrm{~nm}$ against a reagent blank without homogenate. NP-SH in $\mathrm{nmol} / \mathrm{g}$ wet tissue is calculated according to the following equation: Corrected Absorbance of sample $x$ dilution factor/weight of sample in $g$.

\section{Determination of total protein and albumin}

Serum albumin; and serum and tissue total protein (TP) were estimated according to the method of Doumas by CS600 and CS610 kits (Crescent Diagnostics), respectively. The principle is based on the formation of a blue/violet complex when protein peptide bonds react with $\mathrm{Cu}$ (II) ions in alkaline solution (biuret reaction). KNa tartrate and KI Solutions were added as stabilizers. Absorbance was measured at $546 \mathrm{~nm}$ and protein was calculated as (Absorbance of sample /Absorbance of standard) $\times$ concentration of standard.

\section{Histopathological evaluation}

The liver and kidney tissue samples were fixed in $10 \%$ neutral buffered formalin for $24 \mathrm{~h}$ and processed using a VIP tissue processor. The processed tissue were then embedded in paraffin blocks and sections ( $5 \mu \mathrm{m}$ thickness) were cut by a rotary microtome (American Optical, Buffalo, NY, USA). Sections were

Table 1 Effect of DPP on APAP-intoxicated rats serum marker enzymes

\begin{tabular}{llllll}
\hline Treatments $(n=6)$ & Dose $(\mathrm{mg} / \mathrm{kg})$ & AST $(\mathrm{U} / \mathrm{l})$ & ALT $(\mathrm{U} / \mathrm{l})$ & GGT $(\mathrm{U} / \mathrm{l})$ & ALP $(\mathrm{U} / \mathrm{l})$ \\
\hline Normal & & $79.08 \pm 4.33$ & $30.36 \pm 2.38$ & $3.80 \pm 0.19$ & $311.50 \pm 6.27$ \\
APAP & 1000 & $296.16 \pm 9.22^{* * *}$ & $206.66 \pm 16.52^{* * *}$ & $16.75 \pm 0.90^{* * *}$ & $604.00 \pm 6.08^{* * *}$ \\
DPP + APAP & 50 & $280.83 \pm 6.27$ & $195.00 \pm 7.91$ & $15.16 \pm 1.07$ & $573.83 \pm 10.89^{*}$ \\
DPP + APAP & 100 & $269.66 \pm 4.97^{*}$ & $165.00 \pm 3.29^{*}$ & $13.0 \pm 0.54^{* *}$ & $536.16 \pm 12.16^{* *}$ \\
Silymarin + APAP & 10 & $165.00 \pm 6.82^{* * *}$ & $103.51 \pm 6.82^{* * *}$ & $7.53 \pm 0.45^{* * *}$ & $355.16 \pm 10.98^{* * *}$ \\
\hline
\end{tabular}

All values represent mean \pm SEM. ${ }^{*} p<0.05 ;{ }^{* *} p<0.01,{ }^{* * *} p<0.001$; ANOVA, followed by Dunnett's multiple comparison test 
Table 2 Effect of DPP on APAP-intoxicated rats serum lipoproteins of control and experimental rats

\begin{tabular}{lllllll}
\hline Treatments $(n=6)$ & Dose $(\mathrm{mg} / \mathrm{kg})$ & Cholesterol $(\mathrm{mg} / \mathrm{dl})$ & Triglycerides $(\mathrm{mg} / \mathrm{dl})$ & $\mathrm{HDL}(\mathrm{mg} / \mathrm{dl})$ & $\mathrm{LDL}(\mathrm{mg} / \mathrm{dl})$ & $\mathrm{VLDL}(\mathrm{mg} / \mathrm{dl})$ \\
\hline Normal & & $101.36 \pm 4.17$ & $81.20 \pm 3.02$ & $55.91 \pm 2.96$ & $29.21 \pm 5.03$ & $16.24 \pm 0.60$ \\
APAP & 1000 & $184.66 \pm 8.66^{* * *}$ & $150.50 \pm 4.95^{* * *}$ & $25.68 \pm 1.77^{* * *}$ & $128.88 \pm 8.17^{* * *}$ & $30.10 \pm 0.99^{* * *}$ \\
DPP + APAP & 50 & $158.50 \pm 5.42^{*}$ & $135.16 \pm 7.88$ & $39.78 \pm 1.05^{* * *}$ & $91.68 \pm 6.47^{* *}$ & $27.03 \pm 1.57$ \\
DPP + APAP & 100 & $146.66 \pm 4.93^{* *}$ & $107.75 \pm 2.51^{* * *}$ & $46.33 \pm 1.93^{* * *}$ & $78.78 \pm 5.66^{* * *}$ & $21.55 \pm 0.50^{* * *}$ \\
Silymarin + APAP & 10 & $119.33 \pm 3.84^{* * *}$ & $99.56 \pm 4.85^{* * *}$ & $48.90 \pm 2.04^{* * *}$ & $50.52 \pm 2.77^{* * *}$ & $19.91 \pm 0.97^{* * *}$ \\
\hline
\end{tabular}

All values represent mean \pm SEM. ${ }^{*} p<0.05 ;{ }^{* *} p<0.01,{ }^{* * *} p<0.001$; ANOVA, followed by Dunnett's multiple comparison test

stained with hematoxylin and eosin $(\mathrm{H} \& \mathrm{E})$, and then examined microscopically for pathomorphological changes.

\section{Statistical analysis}

One-way analysis of variance (ANOVA) was used for data analysis using SPSS software (Statistical Package for the Social Sciences, version 20.0, SPSS Inc., Chicago, IL). All data were expressed as mean \pm SEM. Mean values of the groups were compared using the Dunnett's multiple comparison test. $P<0.05$ was statistically considered significant.

\section{Results}

\section{Analyses of serum hepatic enzyme profiles}

In a first series of experiments, we explored the effect of DPP on serum markers of hepatic injury. To this end, treatment of rats with APAP significantly increased the levels of the enzymes AST, ALT, GGT and ALP. Pretreatment of rats with DPP significantly and dose-dependently mitigated these effects (Table 1). The effect of DPP was significantly more pronounced at $100 \mathrm{mg} / \mathrm{kg}$. The positive control silymarin, a hepatoprotective agent, significantly curtailed APAP triggered alterations in serum biomarkers (Table 1).

\section{Effect of DPP on serum lipoproteins levels}

Next, we analyzed markers of dyslipidemia fostered by hepatic injury. As a result, administration of rats with DPP prior to APAP intoxication dose-dependently abated the changes in serum levels of cholesterol, triglycerides, LDL, VLDL and HDL (Table 2). The positive control silymarin significantly attenuated alterations in serum lipoproteins induced by APAP intoxication (Table 2).

\section{Determination of renal biochemical parameters}

Further experiments addressed the modulation of extra hepatic biochemical parameters associated with APAP triggered renal injury. As depicted in Table 3, administration of APAP significantly enhanced the levels of urea, uric acid and creatinine which were significantly and dose-dependently blunted by DPP. The positive control silymarin similarly mitigated APAP-elicited changes in the renal biochemical parameters (Table 4).

\section{Analyses of electrolytes}

An additional series of experiments examined whether DPP influenced APAP-induced plasma electrolyte imbalance. As shown in Table 4. DPP suspension significantly blunted APAP-induced dysregulation in plasma sodium, potassium and calcium levels, an effect more pronounced at $100 \mathrm{mg} / \mathrm{kg}$ DPP. The positive control silymarin significantly curtailed APAP-elicited electrolyte imbalance (Table 4).

\section{Malondialdehyde, nonprotein-sulfhydryls and total protein determination in liver tissue}

In view of the modulatory effect of DPP on APAPinduced hepatic injury, further experiments explored the underlying mechanism. It was found that the treatment with DPP influences APAP-triggered redox imbalance in the rat hepatic tissue. To this end, we determined hepatic malondialdehyde (MDA), nonprotein sulfhydryls (NP-SH) and total protein levels. As shown in Figs. 1, 2 and 3, APAP treatment

Table 3 Effect of DPP on APAP-intoxicated rats serum creatinine, urea, uric acid

\begin{tabular}{llll}
\hline Treatments $(n=6)$ & Dose $(\mathrm{mg} / \mathrm{kg})$ & Creatinine $(\mathrm{mg} / \mathrm{dl})$ & Urea $(\mathrm{mg} / \mathrm{dl})$ \\
\hline Normal & & $1.12 \pm 0.11$ & $40.85 \pm 2.14$ \\
APAP & 1000 & $3.84 \pm 0.11^{* * *}$ & $183.83 \pm 5.97^{* * *}$ \\
DPP + APAP & 50 & $2.45 \pm 0.18^{* * * 13}$ & $136.83 \pm 6.75^{* * *}$ \\
DPP + APAP & 100 & $2.40 \pm 0.16^{* * *}$ & $9.23^{* * *}$ \\
Silymarin + APAP & 10 & $1.82 \pm 0.08^{* * *}$ & $8.11 \pm 0.26$ \\
\hline
\end{tabular}

All values represent mean \pm SEM. ${ }^{* * *} p<0.001$; ANOVA, followed by Dunnett's multiple comparison test 
Table 4 Effect of DPP on APAP-intoxicated rats serum sodium, potassium and calcium

\begin{tabular}{lllll}
\hline Treatments $(n=6)$ & Dose $(\mathrm{mg} / \mathrm{kg})$ & Sodium $(\mathrm{mg} / \mathrm{dl})$ & Potassium $(\mathrm{mg} / \mathrm{dl})$ & $\begin{array}{l}\text { Calcium } \\
(\mathrm{mg} / \mathrm{dl})\end{array}$ \\
\hline Normal & & $96.45 \pm 3.67$ & $4.33 \pm 0.22$ & $4.50 \pm 0.20$ \\
APAP & 1000 & $148.85 \pm 2.19^{* * *}$ & $12.46 \pm 0.62^{* * *}$ & $11.94 \pm 1.02^{* * *}$ \\
DPP + APAP & 50 & $144.68 \pm 1.88$ & $10.51 \pm 0.44^{*}$ & $10.61 \pm 0.58$ \\
DPP + APAP & 100 & $131.64 \pm 3.06^{* *}$ & $8.46 \pm 0.33^{* * *}$ & $8.83 \pm 0.86^{*}$ \\
Silymarin + APAP & 10 & $115.22 \pm 4.20^{* * *}$ & $6.61 \pm 0.47^{* * *}$ & $5.98 \pm 1.11^{* *}$ \\
\hline
\end{tabular}

All values represent mean \pm SEM. ${ }^{*} p<0.05 ;{ }^{* *} p<0.01,{ }^{* * *} p<0.001 ;$ ANOVA, followed by Dunnett's multiple comparison test

significantly upregulated hepatic MDA levels, an effect that was significantly and dose-dependently curtailed by DPP and the positive control silymarin. Similarly, DPP treatment counteracted the decrease in hepatic $\mathrm{NP}-\mathrm{SH}$ and total protein levels induced by APAP treatment. These results suggest the influence of antioxidant effects of DPP in curtailing APAP-induced hepatic damage.

\section{Determination of serum albumin, bilirubin and total protein}

Next, we determined the influence of DPP treatment on APAP triggered changes in serum proteins and bilirubin. As depicted in Table 5, APAP treatment significantly enhanced serum bilirubin concentration and significantly reduced serum albumin as well as total protein concentration, an effect significantly mitigated by DPP pretreatment $(100 \mathrm{mg} / \mathrm{kg})$ indicating that DPP elicit hepatoprotective effects in vivo. The positive control silymarin significantly blunted APAP triggered alterations in serum bilirubin, albumin and total proteins (Table 5).

\section{Malondialdehyde, nonprotein-sulfhydryls and total protein determination in kidney tissue}

To mechanistically corroborate the extrahepatic antioxidant effects of DPP treatment in APAP-treated rats we determined MDA, NP-SH and total protein levels in renal tissue. As shown in Figs. 4, 5 and 6, DPP treatment mitigated APAP triggered upregulation in MDA levels and downregulation in NP-SH and total protein levels, indicating that DPP has antioxidant effects in extra-hepatic renal tissue. The positive control silymarin similarly blunted APAP triggered alterations in renal MDA, NP-SH and total protein levels (Figs. 4, 5 and 6).

\section{Histopathological assessment of rat liver and kidney tissue}

Histopathological analyses were carried out to elucidate the impact of DPP treatment on APAP-induced morphological alteration of liver and kidney tissue, depicted in Figs. 7 and 8.

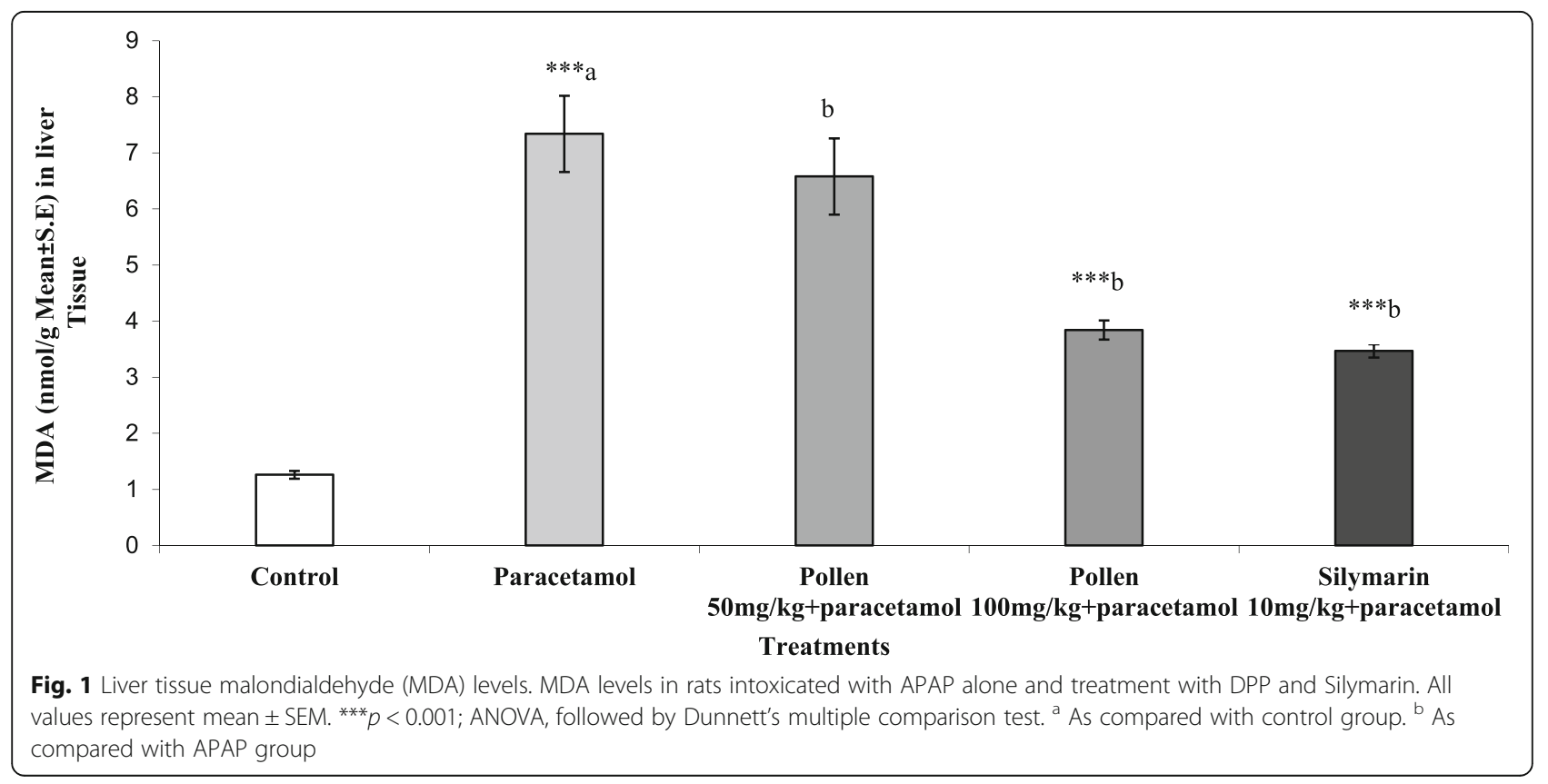




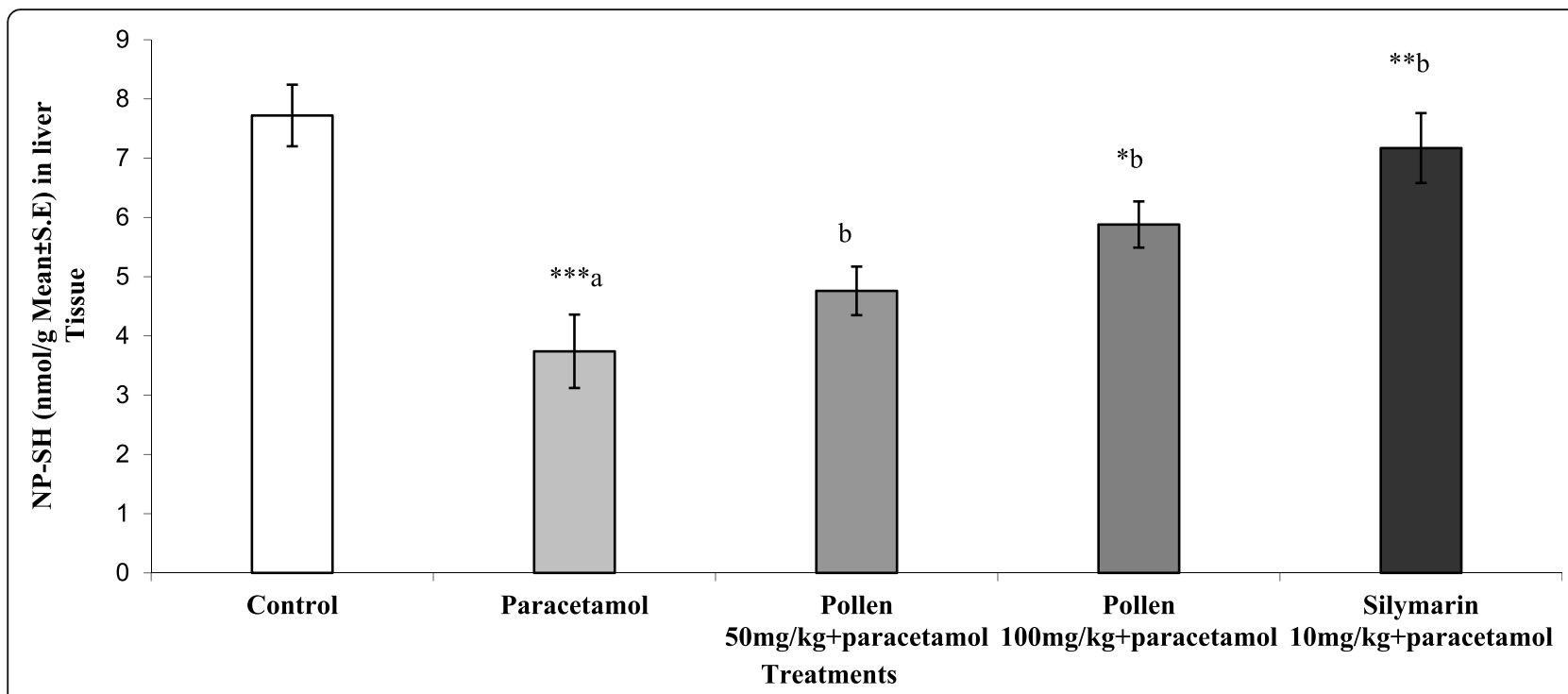

Fig. 2 Liver tissue Non Protein sulfhydryls (NP-SH) levels. NP-SH levels in rats intoxicated with APAP alone and treatment with DPP and Silymarin. All values represent mean \pm SEM. ${ }^{*} p<0.05 ;{ }^{* *} p<0.01$, ${ }^{* * *} p<0.001$; ANOVA, followed by Dunnett's multiple comparison test. ${ }^{a}$ As compared with control group. ${ }^{b}$ As compared with APAP group

Figure 7 control group showed normal hepatic tissue. APAP only treated, group revealed massive focal hepatocytes necrosis, degeneration concomitant with vacuolization. DPP $(50 \mathrm{mg} / \mathrm{kg})$ plus APAP treated, group showed a mild degeneration and hemorrhage signs. DPP $(100 \mathrm{mg} / \mathrm{kg})$ plus APAP treated, group showed insignificant changes in far of vacuolization indicated presence of bi-nucleated hepatic cells. Silymarin plus APAP treated animals did not reveal any significant pathological changes in the liver tissues.
Figure 8 control group revealed normal renal tissue. APAP only treated group exhibited sever tissue damage in the form of focal tubular degeneration for both distal and proximal convoluted tubules with tubular dilation. Group DPP $(50 \mathrm{mg} / \mathrm{kg})$ plus APAP, showed tubular degeneration. Treatment with DPP (100 mg/ $\mathrm{kg}$ ) plus APAP, revealed mild tubular degeneration. Animals revealed Silymarin plus APAP almost showed normal tubular and glomerular tissues architecture.

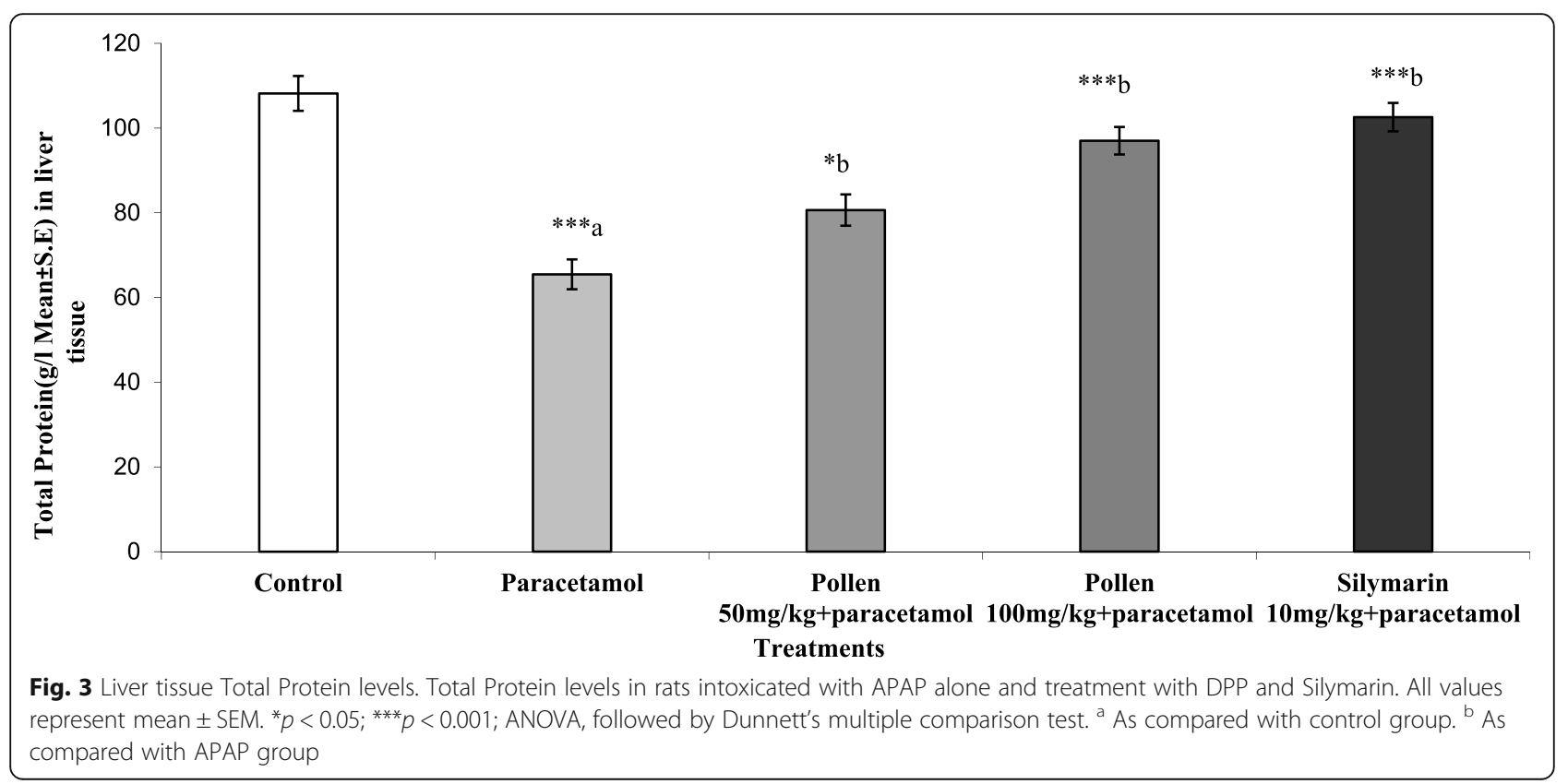


Table 5 Effect of DPP on APAP-intoxicated rats serum albumin, bilirubin, and total protein

\begin{tabular}{lllll}
\hline Treatments $(n=6)$ & Dose $(\mathrm{mg} / \mathrm{kg})$ & Albumin $(\mathrm{g} / \mathrm{dl})$ & Bilirubin $(\mathrm{g} / \mathrm{dl})$ & Total Protein $(\mathrm{mg} / \mathrm{dl})$ \\
\hline Normal & & $5.741 \pm 0.23$ & $0.53 \pm 0.02$ & $5.025 \pm 0.19$ \\
APAP & 1000 & $1.55 \pm 0.10^{* * *}$ & $2.66 \pm 0.11^{* * *}$ & $2.53 \pm 0.18^{* * *}$ \\
DPP + APAP & 50 & $1.77 \pm 0.15$ & $2.33 \pm 0.7$ & $2.62 \pm 0.15$ \\
DPP + APAP & 100 & $2.23 \pm 0.11^{* *}$ & $2.02 \pm 0.08^{* *}$ & $3.18 \pm 0.15^{*}$ \\
Silymarin+ APAP & 10 & $4.46 \pm 0.23^{* * *}$ & $1.12 \pm 0.07^{* * *}$ & $3.91 \pm 0.33^{* *}$ \\
\hline
\end{tabular}

All values represent mean \pm SEM. ${ }^{*} p<0.05 ;{ }^{* *} p<0.01,{ }^{* * *} p<0.001$; ANOVA, followed by Dunnett's multiple comparison test

\section{Discussion}

The present study unravels the hitherto unknown, hepatic and renal protective effects of DPP treatment against APAP-elicited toxicity in rats. To this end, DPP treatment mitigated APAP-triggered alterations in biomarkers of hepatic as well as renal function in rats. Our data further shows that DPP treatment curtailed APAP-induced oxidative stress in both hepatic and renal tissue, thus, ameliorating redox-sensitive tissue damage.

APAP is widely used as an antipyretic and analgesic drug and its toxicity encompasses both hepatic and renal failure in humans and experimental animal models [41-43]. As APAP is metabolized in the liver by glucuronidation and sulfation pathways, an overdose triggers a saturation of these pathways resulting in a shift towards CYP450mediated depletion of hepatic glutathione [44]. Downregulation of hepatic glutathione further elicits mitochondrial dysfunction, generation of reactive oxygen species and tissue necrosis [44]. On the other hand, extra-hepatic toxicity of APAP such as renal injury can occur at lower doses [45]. APAP triggered acute nephrotoxicty is characterized by both functional and morphological evidence of proximal tubular injury which, in turn, is associated with oxidative stress, downregulation of the signaling molecule Bcl-xL, caspase activation, endoplasmic reticulum stress and APAPtotic cell death [46-48]. APAP metabolites were further shown to exert their toxic effects by covalently binding to hepatic and renal DNA [49]. Along those lines, whether DPP extract influences those histological and molecular alterations requires further investigation.

Recent studies of the beneficial effect of some natural compounds against the elevated serum biochemical markers due to APAP-induced hepatorenal toxicity in rats [50-53]. Our results showed DPP caused a significantly diminished the elevated serum hepatic and renal enzymes and lipid profiles. On the other hand our data reveal that DPP treatment confers a robust antioxidant effect on APAP-induced alterations in hepatic and renal malondialdehyde as well as non-protein sulfhydryl concentrations. Mechanistically, redox sensitivity of the protective effects of DPP is possibly mediated by a multitude of its bioactive constituents. DPP were shown to be rich in nutrients such as amino acids, vitamins and minerals [54]. Remarkably,

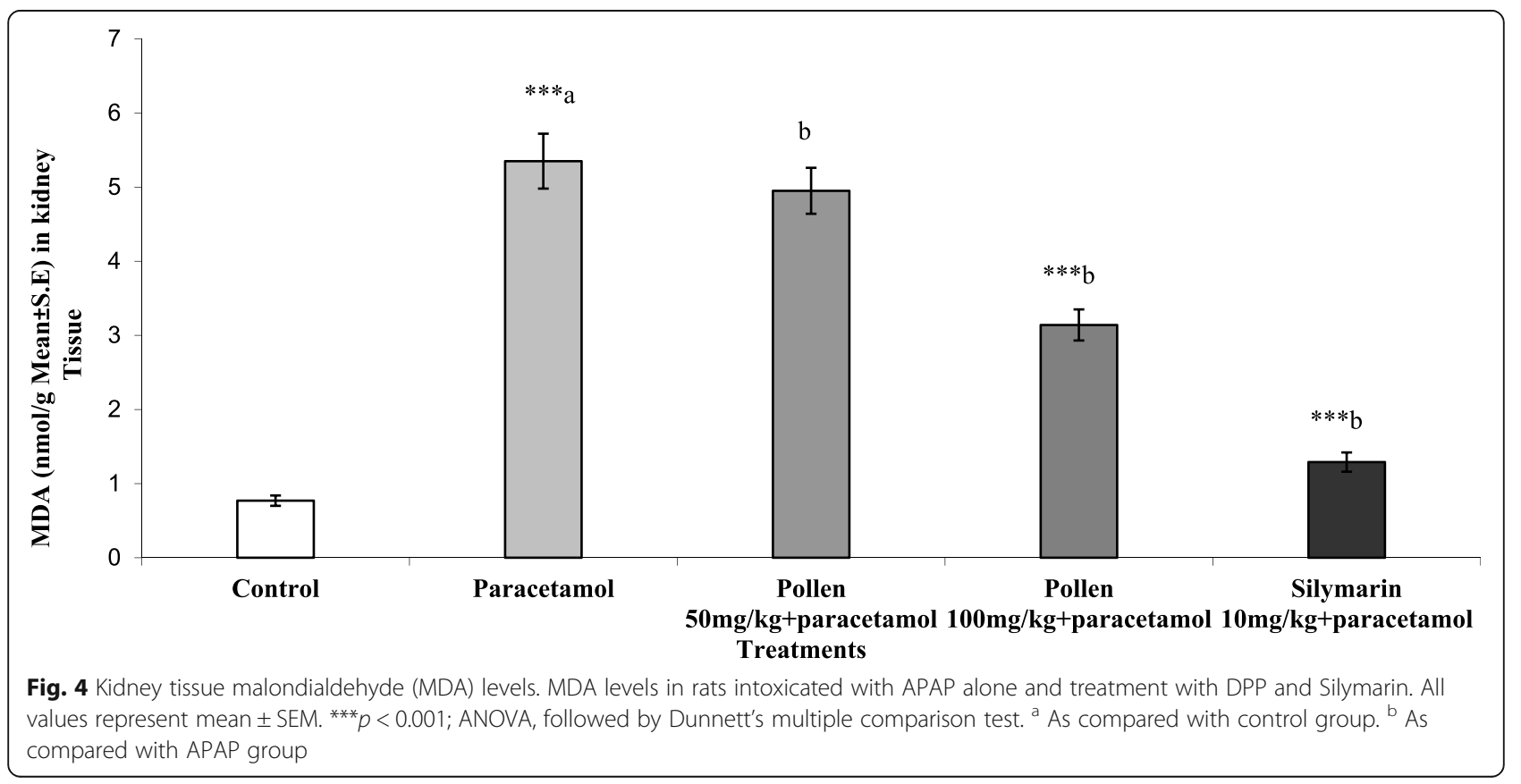




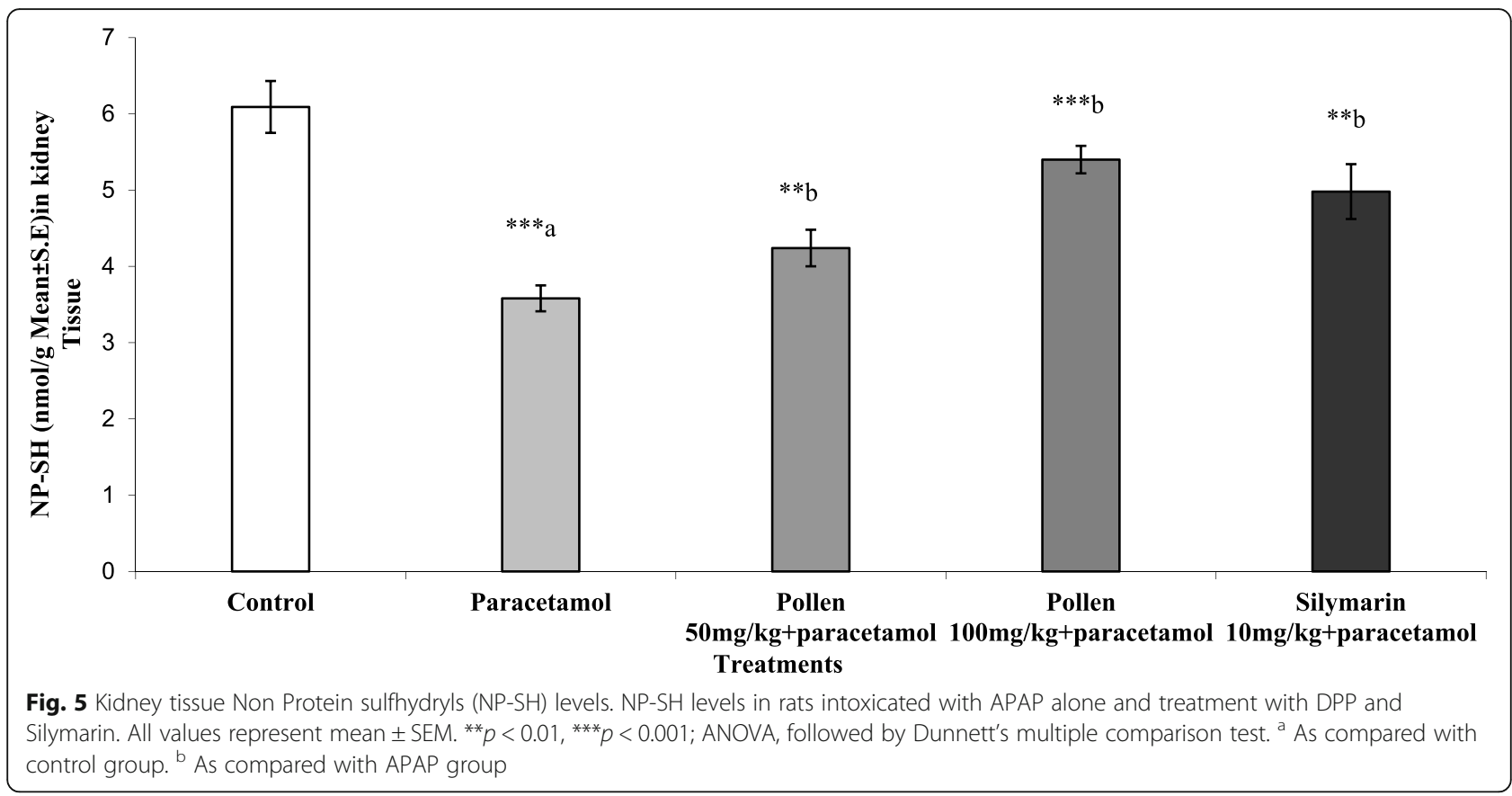

DPP were shown to contain phytochemicals such as rutin, flavonoids and phenolic compounds that possess antioxidant activity [54]. By the same token, these phytochemicals were also shown to possess hepato- and nephroprotective activities in animal models [42, 54-57]. Intriguingly, DPP treatment was recently shown to attenuate the deleterious effects of cadmium-induced testicular toxicity by inhibiting enhanced oxidative stress [28]. To the best of our knowledge, the hepatorenal protective effects of DPP have not been reported.

Additional putative mechanisms that may contribute to the protective effects of DPP treatment include its previously reported anti-inflammatory potential [27], as APAP toxicity triggers an inflammatory response in the hepatic tissue [58]. Compelling evidence suggests that bioactive constituents of DPP possess anti-inflammatory activities in animal models [59-62]. It is, therefore, tempting to speculate that anti-inflammatory effect of DPP and its constituents [63] further attenuate APAP triggered hepatorenal damage. Taken together, treatment with DPP confers protection against APAP-elicited hepato- and nephrotoxicity in rat, an effect that is mediated, in large part, by its in vivo and in vitro $[64,65]$ antioxidant and free-radical scavenging properties.

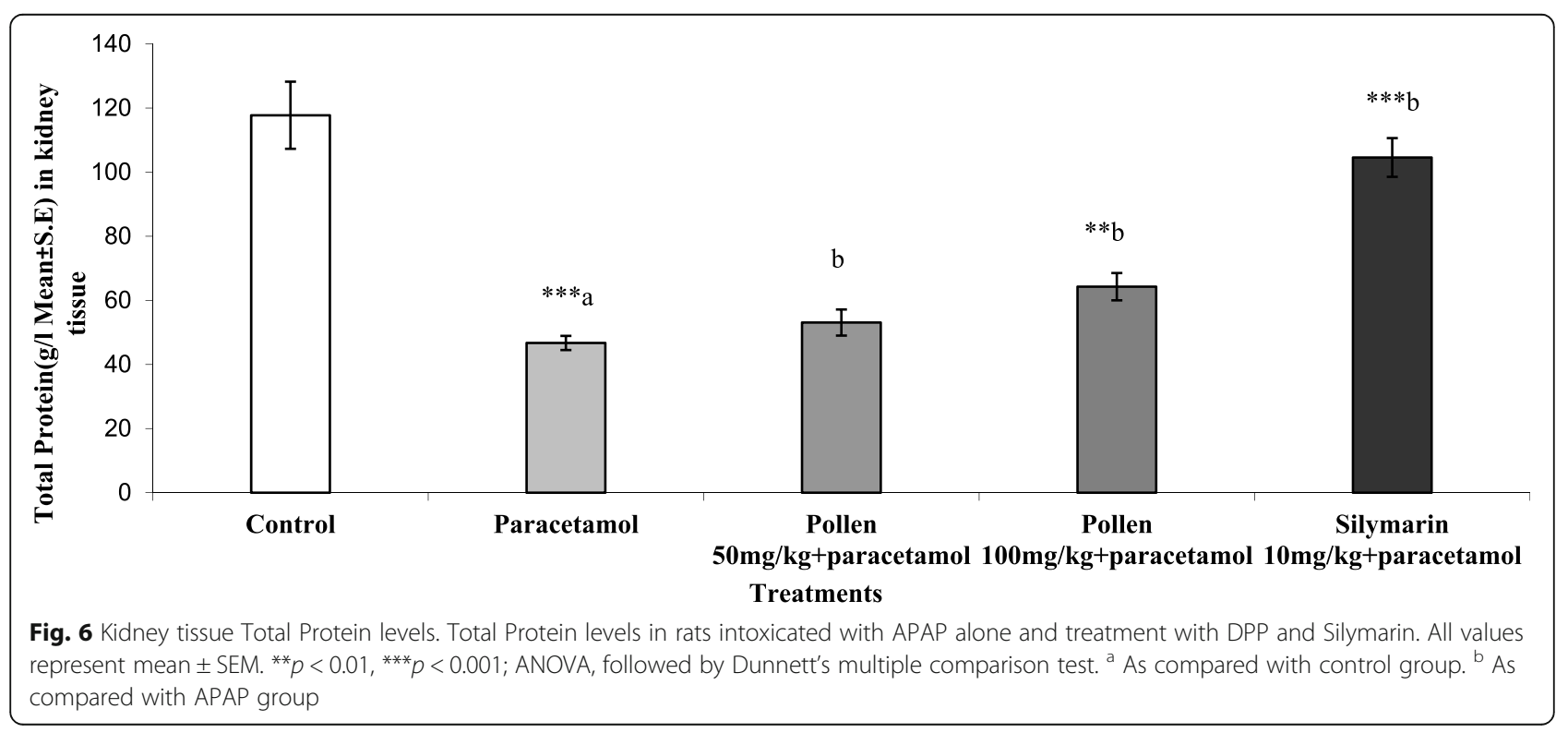



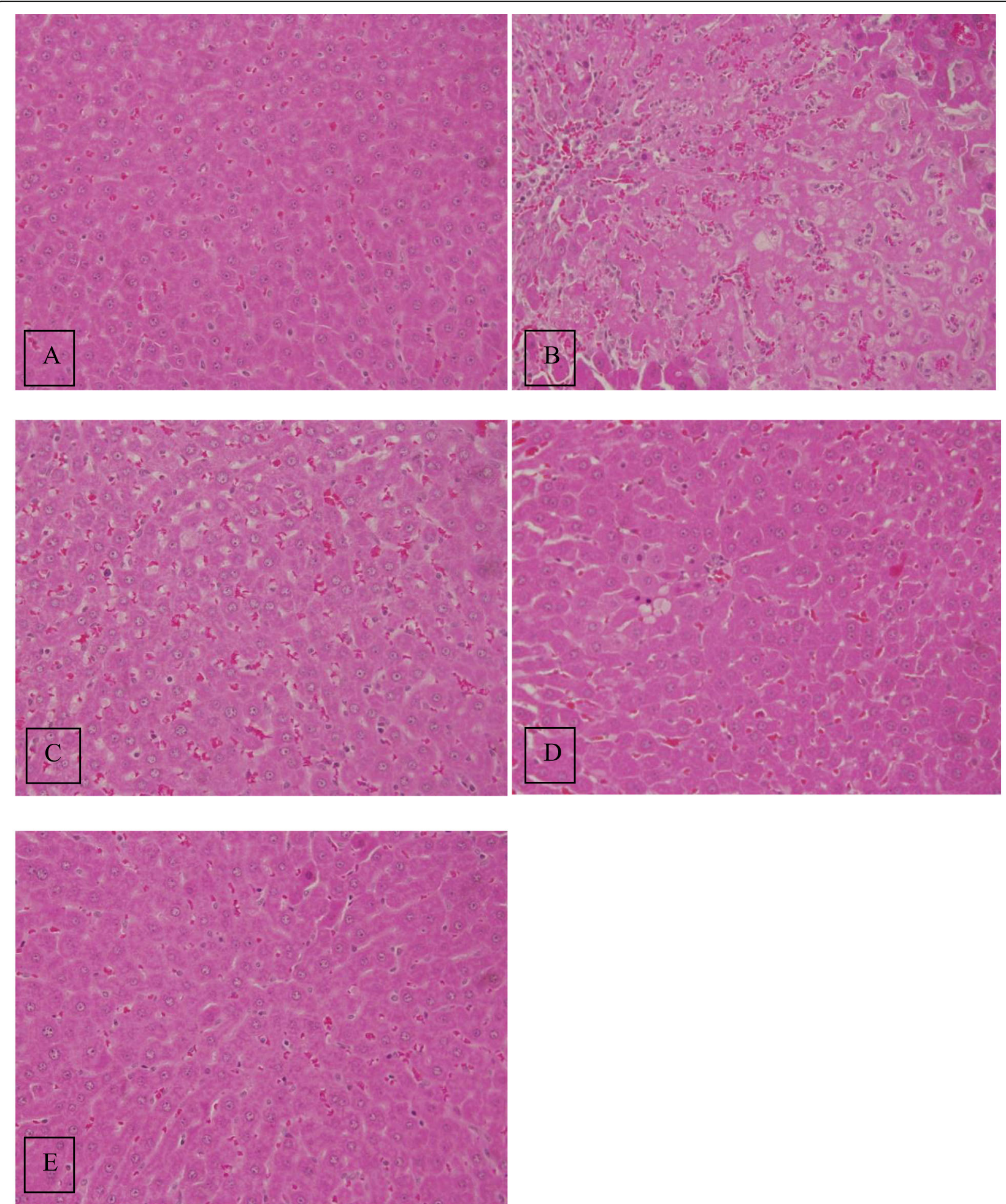

Fig. 7 All sections of liver stained with ( $\mathrm{H}$ \&E) were viewed and evaluated for pathological changes by using a light microscope (Eclipse i80, Nikon, Japan). The required images were taken with Nikon mounted digital camera (OXM 1200C, Nikon, Japan (400X). a- Normal Control b- Received APAP $1000 \mathrm{mg} / \mathrm{kg}$ c- DPP $(50 \mathrm{mg} / \mathrm{kg})+$ APAP d- DPP $(100 \mathrm{mg} / \mathrm{kg})+$ APAP e- Silymarin + APAP 

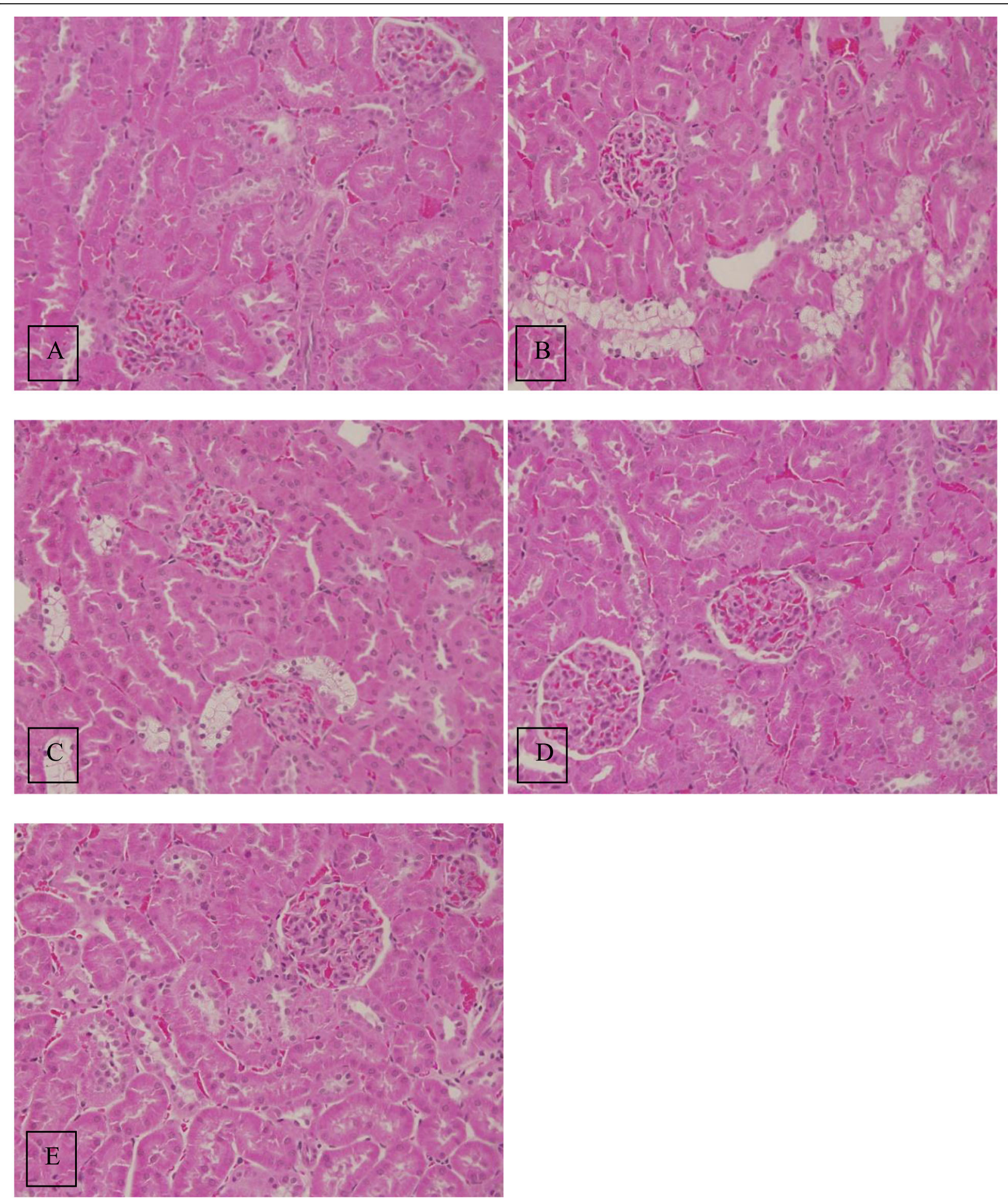

Fig. 8 All sections of Kidney stained with ( $H$ \& E) were viewed and evaluated for pathological changes by using a light microscope (Eclipse i80, Nikon, Japan). The required images were taken with Nikon mounted digital camera (OXM 1200C, Nikon, Japan (400X). a- Normal, Control, b- Received APAP $1000 \mathrm{mg} / \mathrm{kg}$, c- DPP (50 mg/kg) + APAP, d- DPP (100 mg/kg) + APAP, e- Silymarin + APAP 


\section{Conclusions}

APAP caused oxidative damage in the hepatic and renal tissue of the experimental animals, and that could be averted by the treatment of DPP. Protective role of DPP could be due to its antioxidant, membrane stabilizing as well as antihyperlipidemic actions exerted through modulation of biochemical markers. The wide range of pharmacological effects of DPP may be attributed to the powerful and beneficial ingredients including phenolics, flavonoids, carotenoids, vitamins, minerals, amino acids, fatty acids and organic acids. In addition, results also suggest that DPP might be beneficial for the finding of therapeutic potential against APAP induced hepatic and renal toxicity.

\begin{abstract}
Abbreviations
ALP: Alkaline Phosphatase; ALT: Alanine transaminase; ANOVA: Analysis of variance; APAP: Paracetamol (Acetaminophen); AST: Aspartate transaminase; DPP: Date palm pollen; GGT: $\gamma$-Glutamyl transferase; HDL-C: High-density lipoprotein cholesterol; LDL-C: Low-density lipoprotein cholesterol; MDA: Malondialdehyde; NP-SH: Non-protein sulfhydryls; SIL: Silymarin; TC: Total cholesterol; TG: Triglycerides; TP: Total Protein; VLDL-C: Very lowdensity lipoprotein-cholesterol
\end{abstract}

\section{Acknowledgments}

The authors would like to thank Mr. Malik Sawood Ahmed for his technical assistance.

\section{Authors' contributions}

This work was carried out in collaboration between all authors. Authors AKAA designed the study; MSAS, supervised and procured the Date Palm Pollen sample, authenticated the material and provided the laboratory facilities. Author SR carried out the experimental and interpreted the data. $A A B$ have participated in statistical analysis. RA collecting literature and typed the manuscript and prepared the Pollen solution. KEl, under took the histopathological assessment of the tissues. All authors read and approved the final Manuscript.

\section{Funding}

None.

\section{Availability of data and materials}

The datasets used and/or analysed during the current study are available from the corresponding author on reasonable request.

\section{Ethics approval and consent to participate}

The use of laboratory animals were approved by the Ethics Committee of the Experimental Animal Care Society, King Saud University (KSU), Riyadh, Saudi Arabia.

\section{Consent for publication}

Not applicable.

\section{Competing interests}

The authors declare that they have no competing interests regarding the publication of this paper.

\section{Author details}

${ }^{1}$ Scientific Research Center, Medical Service Department (MSD), Ministry of Defense, P.O. Box: 22454, Riyadh 11495, Kingdom of Saudi Arabia. 2Department of Pharmacognosy, Medicinal, Aromatic and Poisonous Plants Research Center, College of Pharmacy, King Saud University, P.O. Box 2457, Riyadh 11451, Saudi Arabia. ${ }^{3}$ Department of ENT, Prince Sultan Military Medical City, P.O. Box 7897, Riyadh 11159, Saudi Arabia. ${ }^{4}$ Department of Zoology, College of Science, King Saud University, P.O. Box 2455, Riyadh 11451, Saudi Arabia.
Received: 28 August 2019 Accepted: 22 January 2020

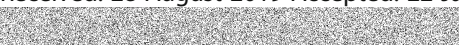

\section{References}

1. Mallhi TH, Qadir Ml, Ali M, Ahmad B, Khan YH, Rehman A. Review: Ajwa date (Phoenix dactylifera) an emerging plant in pharmacological research. Pak J Pharm Sci. 2014;27:607-16.

2. Vayalil PK. Date fruits (Phoenix dactylifera Linn): an emerging medicinal food. Crit Rev Food Sci Nutr. 2012;52:249-71.

3. El-Arem A, Saafi EB, Ghrairi F, Thouri A, Zekri M, Ayed A, et al. Aqueous date fruit extract protects against lipid peroxidation and improves antioxidant status in the liver of rats subchronically exposed to trichloroacetic acid. J Physiol Biochem. 2014a;70:451-64.

4. Borochov-Neori H, Judeinstein S, Greenberg A, Volkova N, Rosenblat M, Aviram M. Antioxidant and antiatherogenic properties of phenolic acid and flavonol fractions of fruits of 'Amari' and 'Hallawi' date (Phoenix dactylifera L.) varieties. J Agric Food Chem. 2015;63:3189-95.

5. Zhang CR, Aldosari SA, Vidyasagar PS, Nair KM, Nair MG. Antioxidant and anti-inflammatory assays confirm bioactive compounds in Ajwa date fruit J Agric Food Chem. 2013;61:5834-40.

6. Abdelaziz DH, Ali SA. The protective effect of Phoenix dactylifera L. seeds against CCl4-induced hepatotoxicity in rats. J Ethnopharmacol. 2014;155:736-43.

7. El-Arem A, Zekri M, Thouri A, Saafi EB, Ghrairi F, Ayed A, et al. Oxidative damage and alterations in antioxidant enzyme activities in the kidneys of rat exposed to trichloroacetic acid: protective role of date palm fruit. J Physiol Biochem. 2014b:70:297-309.

8. Mahdhi A, Bahi A, Mzah D, Bakhrouf A. Use of mixture design to construct a consortium of date palm (Phoenix dactylifera L.) fruit extract and potentially probiotic Bacillus strain to confer protection against vibriosis in Artemia culture. J Sci Food Agric. 2013;93:3850-5.

9. Karasawa K, Otani H. Anti-allergic properties of a matured fruit extract of the date palm tree (Phoenix dactylifera L.) in mite-sensitized mice. J Nutr Sci Vitaminol (Tokyo). 2012;58:272-7.

10. Karasawa K, Uzuhashi Y, Hirota M, Otani H. A matured fruit extract of date palm tree (Phoenix dactylifera L.) stimulates the cellular immune system in mice. J Agric Food Chem. 2011;59:11287-93.

11. Pujari RR, Vyawahare NS, Kagathara VG. Evaluation of antioxidant and neuroprotective effect of date palm (Phoenix dactylifera L.) against bilateral common carotid artery occlusion in rats. Indian J Exp Biol. 2011:49:627-33.

12. Boulenouar N, Marouf A, Cheriti A. Antifungal activity and phytochemical screening of extracts from Phoenix dactylifera L. cultivars. Nat Prod Res. 2011:25:1999-2002.

13. Vayalil PK. Antioxidant and antimutagenic properties of aqueous extract of date fruit (Phoenix dactylifera L. Arecaceae). J Agric Food Chem. 2002;50:610-7.

14. Souli A, Sebai H, Rtibi K, Chehimi L, Sakly M, Amri M, et al. Effects of dates pulp extract and palm sap (Phoenix dactylifera L.) on gastrointestinal transit activity in healthy rats. J Med Food. 2014;17:782-6.

15. Subash S, Essa MM, Al-Asmi A, Al-Adawi S, Vaishnav R, Guillemin GJ. Effect of dietary supplementation of dates in Alzheimer's disease APPsw/2576 transgenic mice on oxidative stress and antioxidant status. Nutr Neurosci. 2015;18:281-8.

16. Martin-Sanchez AM, Cherif S, Ben-Abda J, Barber-Valles X, Perez-Alvarez JA, Sayas-Barbera E. Phytochemicals in date co-products and their antioxidant activity. Food Chem. 2014;158:513-20.

17. Al-Farsi M, Alasalvar C, Morris A, Baron M, Shahidi F. Comparison of antioxidant activity, anthocyanins, carotenoids, and phenolics of three native fresh and sun-dried date (Phoenix dactylifera L.) varieties grown in Oman. J Agric Food Chem. 2005:53:7592-9.

18. Hong YJ, Tomas-Barberan FA, Kader AA, Mitchell AE. The flavonoid glycosides and procyanidin composition of Deglet Noor dates (Phoenix dactylifera). J Agric Food Chem. 2006;54:2405-11.

19. Borochov-Neori H, Judeinstein S, Greenberg A, Volkova N, Rosenblat M, Aviram M. Date (Phoenix dactylifera L.) fruit soluble phenolics composition and anti-atherogenic properties in nine Israeli varieties. J Agric Food Chem. 2013:61:4278-86.

20. Mohamed Lemine FM, Mohamed Ahmed MV, Ben Mohamed Maoulainine L, Bouna Zel A, Samb A, OB AO. Antioxidant activity of various Mauritanian date palm (Phoenix dactylifera L.) fruits at two edible ripening stages. Food Sci Nutr. 2014;2:700-5.

21. Mohamed RM, Fageer AS, Eltayeb MM, Mohamed Ahmed IA. Chemical composition, antioxidant capacity, and mineral extractability of Sudanese date palm (Phoenix dactylifera L.) fruits. Food Sci Nutr. 2014;2:478-89. 
22. Jassim SA, Naji MA. In vitro evaluation of the antiviral activity of an extract of date palm (Phoenix dactylifera L.) pits on a pseudomonas phage. Evid Based Complement Alternat Med. 2010;7:57-62.

23. Khatami M, Pourseyedi S. Phoenix dactylifera (date palm) pit aqueous extract mediated novel route for synthesis high stable silver nanoparticles with high antifungal and antibacterial activity. IET Nanobiotechnol. 2015;9:184-90.

24. Diab KA, Aboul-Ela El. In vivo Comparative Studies on Antigenotoxicity of Date Palm (Phoenix dactylifera L.) Pits Extract against DNA Damage Induced by N-Nitroso-N-methylurea in Mice. Toxicol Int. 2012;19:279-86.

25. Kwaasi AA, Parhar RS, Harfi H, Tipirneni P, Al-Sedairy ST. Characterization of antigens and allergens of date palm (Pheonix dactylifera) pollen. Immunologic assessment of atopic patients by whole extract and its fractions [corrected]. Allergy. 1992;47:535-44.

26. Elkerm Y, Tawashi R. Date palm pollen as a preventative intervention in radiation- and chemotherapy-induced oral mucositis: a pilot study. Integr Cancer Ther. 2014;13:468-72.

27. Elberry AA, Mufti ST, Al-Maghrabi JA, Abdel-Sattar EA, Ashour OM, Ghareib SA, et al. Anti-inflammatory and antiproliferative activities of date palm pollen (Phoenix dactylifera) on experimentally-induced atypical prostatic hyperplasia in rats. J Inflamm (Lond). 2011;8:40.

28. El-Neweshy MS, El-Maddawy ZK, El-Sayed YS. Therapeutic effects of date palm (Phoenix dactylifera L.) pollen extract on cadmium-induced testicular toxicity. Andrologia. 2013;45:369-78.

29. Mehraban F, Jafari M, Akbartabar Toori M, Sadeghi H, Joodi B, Mostafazade $M$, et al. Effects of date palm pollen (Phoenix dactylifera L.) and Astragalus ovinus on sperm parameters and sex hormones in adult male rats. Iran J Reprod Med. 2014;12:705-12.

30. Reitman S, Frankel S. A colorimetric method for the determination of serum glutamic oxalacetic and glutamic pyruvic transaminases. Am J Clin Pathol. 1957;28:56-63

31. Fiala S, Fiala AE, Dixon B. Gamma-glutamyl transpeptidase in transplantable chemically induced rat hepatomas and spontaneous mouse hepatomas. J Natl Cancer Inst. 1972;48:1393-409.

32. King EJ, Armstrong AR. Calcium, phosphorus and phosphate. In: Varley $H$, editor. Practical Clinical Biochemistry. New Delhi: CBS Publishers; 1988. p. 458

33. Stiehl A. Hyperbilirubinemia in liver diseases. Fortschr Med. 1982;100:842-5.

34. Demacher PNM, Hijamaus AGM. A study of the use of polyethylene glycol in estimating cholesterol. Clin Chem. 1980;26:1775-8.

35. Burstein M, Scholnick HR. Turbidimetric estimation of chylomicrons and very low density lipoproteins in human sera after precipitation by sodium lauryl sulfate. Biomedicine. 1973;19:16-9.

36. Foster LB, Dunn RT. Stable reagents for the determination of serum triglycerides by a colorimetric Hantzch condensation method. J Clin Chem. 1973;19:338-40.

37. Munan L, Kelly A, PetitClerc C, Billon B. Associations with body weight of selected chemical constituents in blood: epidemiologic data. Clin Chem 1978:24:772-7.

38. Fossati P, Prencipe L, Berti G. Use of 3,5-dichloro-2-hydroxybenzenesulfonic acid/4-aminophenazone chromogenic system in direct enzymic assay of uric acid in serum and urine. Clin Chem. 1980;26:227-31.

39. Utley HC, Bernheim F, Hochslein P. Effect of sulfhydryl reagent onperoxidation in microsome. Arch Biochem Biophys. 1967;260:521-31.

40. Sedlak J, Lindsay RH. Estimation of total, protein-bound, and nonprotein sulfhydryl groups in tissue with Ellman's reagent. Anal Biochem. 1968;25: 192-205.

41. Blakely P, McDonald BR. Acute renal failure due to acetaminophen ingestion: a case report and review of the literature. J Am Soc Nephrol. 1995;6:48-53.

42. Aseervatham GS, Sivasudha T, Sasikumar JM, Christabel PH, Jeyadevi R, Ananth DA. Antioxidant and hepatoprotective potential of Pouteria campechiana on acetaminophen-induced hepatic toxicity in rats. J Physiol Biochem. 2014;70:1-14

43. El-Agamy DS, Makled MN, Gamil NM. Protective effects of BML-111 against acetaminophen-induced acute liver injury in mice. J Physiol Biochem. 2014; 70:141-9.

44. Jaeschke H, Xie Y, McGill MR. Acetaminophen-induced liver injury: from animal models to humans. J Clin Transl Hepatol. 2014;2:153-61.

45. Hinson JA, Roberts DW, James LP. Mechanisms of acetaminophen induced liver necrosis. Handb Exp Pharmacol. 2010;196:369-405.

46. Lorz C, Justo P, Sanz A, Subira D, Egido J, Ortiz A. APAP-induced renal tubular injury: a role for ER stress. J Am Soc Nephrol. 2004;15:380-9.
47. Lorz C, Justo P, Sanz AB, Egido J, Ortiz A. Role of BCl-xL in APAP-induced tubular epithelial cell death. Kidney Int. 2005;67:592-601.

48. Pradhan S, Mandal S, Roy S, Mandal A, Das K, Nandi DK. Attenuation of uremia by orally feeding alpha-lipoic acid on acetaminophen induced uremic rats. Saudi Pharm J. 2013;21:187-92.

49. Rogers LK, Moorthy B, Smith CV. Acetaminophen binds to mouse hepatic and renal DNA at human therapeutic doses. Chem Res Toxicol. 1997;10:470-6.

50. Adil M, Amit D, Kandhare PG, Venkata S, Kiran S, Raygude SL, Bodhankar. Ameliorative effect of naringin in acetaminophen-induced hepatic and renal toxicity in laboratory rats: role of FXR and KIM-1. Renal Failure. 2016;38:1007-20.

51. Zakaria ZA, Kamisan FH, Omar MH, Mahmood ND, Othman F, Abdul Hamid SS, MNH A. Methanol extract of Dicranopteris linearis L. leaves impedes acetaminophen-induced liver intoxication partly by enhancing the endogenous antioxidant system. BMC Complement Altern Med. 2017;17:271.

52. Abdulkhaleq FM, Alhussainy TM, Badr MM, Khalil AAA, Gammoh O, Ghanim BY, Qinna NA. Antioxidative stress effects of vitamins C, E, and B12, and their combination can protect the liver against acetaminophen-induced hepatotoxicity in rats. Drug Des Devel Ther. 2018;12:3525-33.

53. Abdulrazzaq AM, Badr M, Gammoh O, Abu Khalil AA, Ghanim BY, Alhussainy TM, Qinna NA. Hepatoprotective actions of ascorbic acid, Alpha Lipoic Acid and Silymarin or Their Combination against Acetaminophen-Induced Hepatotoxicity in Rats. Medicina. 2019:55:181.

54. Tahvilzadeh M, Hajimahmoodi M, Rahimi R. The role of date palm (Phoenix dactylifera L) pollen in fertility: a comprehensive review of current evidence. J Evid Based Complementary Altern Med. 2016;21:320-4.

55. Mahmood ND, Mamat SS, Kamisan FH, Yahya F, Kamarolzaman MF, Nasir N, et al. Amelioration of APAP-induced hepatotoxicity in rat by the administration of methanol extract of Muntingia calabura L. leaves. Biomed Res Int. 2014;2014:695678. https://doi.org/10.1155/2014/695678.

56. Olaleye MT, Amobonye AE, Komolafe K, Akinmoladun AC. Protective effects of Parinari curatellifolia flavonoids against acetaminophen-induced hepatic necrosis in rats. Saudi J Biol Sci. 2014;21:486-92.

57. Xie W, Chen C, Jiang Z, Wang J, Melzig MF, Zhang X. Apocynum venetum attenuates acetaminophen-induced liver injury in mice. Am J Chin Med. 2015;43:457-76.

58. Antoniades CG, Quaglia A, Taams LS, Mitry RR, Hussain M, Abeles R, et al. Source and characterization of hepatic macrophages in acetaminopheninduced acute liver failure in humans. Hepatology. 2012;56:735-46.

59. Alqasoumi SI, Basudan OA, Al-Rehaily AJ, Abdel-Kader MS. Phytochemical and pharmacological study of Ficus palmata growing in Saudi Arabia. Saudi Pharm J. 2014;22:460-71.

60. El-Aidy WK, Ebeid AA, Sallam AE, Muhammad IE, Abbas AT, Kamal MA, et al. Evaluation of propolis, honey, and royal jelly in amelioration of peripheral blood leukocytes and lung inflammation in mouse conalbumin-induced asthma model. Saudi J Biol Sci. 2015;22:780-8.

61. Kandemir FM, Ozkaraca M, Yildirim BA, Hanedan B, Kirbas A, Kilic K, et al. Rutin attenuates gentamicin-induced renal damage by reducing oxidative stress, inflammation, APAPtosis, and autophagy in rats. Ren Fail. 2015;37:518-25.

62. Muto E, Dell'Agli M, Sangiovanni E, Mitro N, Fumagalli M, Crestani M, et al. Olive oil phenolic extract regulates interleukin-8 expression by transcriptional and posttranscriptional mechanisms in Caco-2 cells. Mol Nutr Food Res. 2015;59:1217-21.

63. Abed El-Azim MH, El-Mesalamy AM, Yassin FA, Khalil SA. Identification phenolic and biological activities of Methanolic extract of date palm pollen (Phoenix dactylifera). J Microb Biochem Technol. 2015;7:1.

64. Farouk A, Metwaly A, Mohsen M. Chemical composition and antioxidant activity of date palm pollen grains (Phoenix dactylifera L. Palmae) essential oil for Siwe cultivar cultivated in Egypt. Middle East J Appl Sci. 2015;5:945-9.

65. Rice-Evans CA, Miller NJ, Paganga G. Antioxidant properties of phenolic compounds. Trends Plant Science. 1997;2:152-9.

\section{Publisher's Note}

Springer Nature remains neutral with regard to jurisdictional claims in published maps and institutional affiliations. 